\title{
Modern management of pulmonary metastases (Preface)
}

The first case of a true pulmonary metastasectomy was described by Weinlechner in 1882 in a patient with a pulmonary metastasis of a sarcoma. The management of pulmonary metastases has evolved considerably over the last century. Understanding the biology of pulmonary metastases is essential to understand the options for treatment. In recent years, doctors have understood that a precise knowledge of the behavior of the original tumor is primarily responsible for successful therapy of lung metastases. However, the heterogeneity of the various epithelial, mesenchymal, sarcomatous or neuroendocrine tumors and their different metastatic behavior also necessitate tumor-specific therapy in the metastatic situation.

In an era of targeted therapies and effective immunotherapies further re-examination of the role of surgery is required. Preoperative Evaluation is extremely important and surgeons should know the indications and contraindications for pulmonary metastasectomy. Tom Treasure has once again fulfilled his role as a critical observer of lung metastases surgery. He has good arguments, we should take him seriously. There is still a lack of prospective, randomized data regarding operative and nonoperative management. We still rely on the better results after R0 resections compared to R1/R2 resections.

In this focused issue of Fournal of Thoracic Disease, we offer a comprehensive synopsis of the management of different primary tumors with lung metastases. The treatment strategies for lung metastases has become more complex. The lack of consensus guidelines forces us to discuss the indication for lung metastasis surgery as part of a multidisciplinary tumor board, which is made up of pneumologists, medical oncologists, radiologists, pathologists and surgeons. With the development of more effective systemic therapy for pulmonary metastatic disease, it is probable that more patients will be considered candidates for a multimodal management of pulmonary metastases from different primary tumors.

\section{Acknowledgments}

Funding: None.

\section{Footnote}

Provenance and Peer Review: This article was commissioned by the editorial office, Fournal of Thoracic Disease for the series "Pulmonary Metastases". The article did not undergo external peer review.

Conflicts of Interest: The author has completed the ICMJE uniform disclosure form (available at http://dx.doi.org/10.21037/ jtd-2019-pm-12). The series "Pulmonary Metastases" was commissioned by the editorial office without any funding or sponsorship. KH served as the unpaid Guest Editor and serves as an unpaid editorial board member of Fournal of Thoracic Disease from May 2019 to April 2021. The author has no other conflicts of interest to declare.

Ethical Statement: The author is accountable for all aspects of this work in ensuring that questions related to the accuracy or integrity of any part of this work are appropriately investigated and resolved.

Open Access Statement: This is an Open Access article distributed in accordance with the Creative Commons AttributionNonCommercial-NoDerivs 4.0 International License (CC BY-NC-ND 4.0), which permits the non-commercial replication and distribution of the article with the strict proviso that no changes or edits are made and the original work is properly cited (including links to both the formal publication through the relevant DOI and the license). See: https://creativecommons.org/ licenses/by-nc-nd/4.0/. 


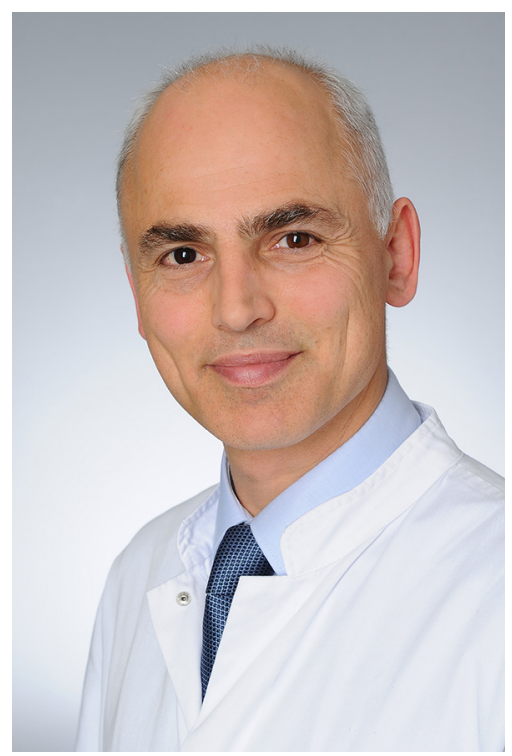

Khosro Hekmat

Khosro Hekmat, MD

Department of Cardiothoracic Surgery, Kerpener Strasse 62, 50937 Cologne, Germany.

(Email:khosro.bekmat@uk-koeln.de)

Submitted Mar 25, 2020. Accepted for publication Jun 12, 2020. doi: $10.21037 /$ jtd-2019-pm-12

View this article at: http://dx.doi.org/10.21037/jtd-2019-pm-12

Cite this article as: Hekmat K. Modern management of pulmonary metastases (Preface). J Thorac Dis 2021;13(4):25832584. doi: $10.21037 /$ jtd-2019-pm-12 